Man in a Chemical World :

the Service of Chemical Industry. By A. Cressy Morrison. Pp. xii +292. (London: Scientific Book Club, n.d.) 2s. $6 d$.

$\mathrm{T}$ HIS volume is an interesting example of the publications of the Scientific Book Club, which are available to members at the uniform price of half-a-crown. Described as "a straight-from-theshoulder account of the activities of chemical industry in converting the discoveries of science into day-today necessities of Everyman", it was originally produced under the auspices of the Executive Committee of the American Chemical Industries Tercentenary, in connexion with the celebration in 1935 of the three-hundredth anniversary of the birth of chemical industry in the United States. Its object, as explained in a foreword, "is to impress the man in the street with the fact that the chemical industries of the United States render a service that touches practically every activity in which he engages". This object is amply attained in a simple and able account of the multifarious achievements of chemistry in industry and everyday life, set out under such headings as "Nature Points the Way", "Chemistry in Overalls", "Keeping Well", "Feeding Millions", "From Papyrus to Television", etc.

A remarkable amount of interesting information has been packed, in an attractive form, into this lowpriced volume. The language is plain, and there are no chemical formulæ to puzzle the lay reader. The text is well printed in a bold type by the Scribner Press in the United States. There are a few ingenious pictorial diagrams; but some of the illustrations are neither instructive nor decorative. J. R.

\section{Die tierischen Parasiten des Menschen}

Von Prof. Walter Stempell. Pp. viii +226. (Jena : Gustav Fischer, 1938.) 12 gold marks.

TN a more convenient and compact form than has hitherto appeared in Germany, this work essays the description of the parasitic fauna of man. Morphological characters are summarized clearly and briefly, but with sufficient detail for identification of all the common parasites. But the rarer forms are also represented (more briefly and in small type) as may be judged by the inclusion of the python parasite Armillifer moniliformis, with five cases recorded from man, and of several insects the connexion of which with human disease is slight; in all, 192 parasites are described. A special feature is the illustration of the text by original schematic figures, which are often accompanied by corresponding photographs.

Since the book is intended to be of service to general zoologists rather than to specialists, morphology takes precedence over physiological, biological, medical and epidemiological aspects, and these are seriously touched upon only in the case of prominent forms, like Plasmodium, Trypanosoma, the tapeworms and a few arthropods. The publishers are to be congratulated on the clearness of the printing and reproduction of illustrations. Wucheria (pp. 134, 135 and index) should be Wuchereria.
Insects of Citrus and other Subtropical Fruits By Prof. Henry J. Quayle. Pp. $x+583$. (Ithaca, N.Y. : Comstock Publishing Co., 1938.) 5 dollars.

7 HE field covered by this work is an extensive one 1 which has not been previously dealt with in a comprehensive book form. Its author has had wide experience of citrus fruit cultivation, and its insect enemies, not only in California but also in other lands. While the book deals with all the main citrusaffecting insects, other subtropical fruit insects are also included, notably those affecting avocado, Persian walnut, vinifera grape, fig, almond, olive, date and some others. The life-histories of the chief pests are described and usually figured. Their natural enemies, where noteworthy, are discussed, and artificial methods of control are fully entered into. The subject matter of this book is up-to-date while the illustrations are often new and original. It is a work that is to be recommended to all concerned with citrus cultivation and more particularly to growers in the United States.

\section{Japanese Minerals in Pictures}

By T. Ito. In 4 vols. Vol. 1. Pp. $x i v+152+27$ plates. (Tokyo: The Author, Tokyo Imperial University, 1937.) 12 yen.

AERY handsomely illustrated mineralogy with A the text in Japanese is Prof. Takeo Ito's "Japanese Minerals in Pictures", of which the first of the four volumes was published in Tokyo in 1937. In 152 pages with 96 crystal drawings the elements, sulphides, and fluorides are described. A fourteenpage key in English gives a brief account of the 38 minerals depicted in the 27 plates, with brief notes on the chief occurrences of the minerals in Japan. Twenty of the plates are reproduced in colour and some of these are among the best coloured representa. tions of minerals printed hitherto. The specimens illustrated are picked specimens and will be the envy of mineral collectors. These plates are the special features of the book and will earn it a place on the shelves of mineralogical libraries all over the world.

\section{Useful Trees and Shrubs :}

Being a Card File of Data on approximately 500 Hardy Woody Plants in Common Use as Ornamentals. Compiled and prepared by Prof. Florence Bell Robinson. 494 Cards. 6 in. $\times 4$ in. (Champaign, Ill. : The Garrard Press, 1938.) 4.50 dollars.

7 HIS card index will be useful to those interested 1 in hardy shrubs and trees, though it is difficult to see that it has any advantage over the available books as a reference work. Certain blank spaces on the cards are said to be an invitation to the user to add his own observations and sketches; if used in this way there is no doubt that much benefit would accrue to the user, and in this case the card index scheme admits of profitable expansion of the record. Notes on the cards refer to habitat ; form ; colour ; bark ; season of foliage ; flower and fruit ; 'cleanliness' (that is, susceptibility to pest and disease); pruning; aspect and value. 